\title{
Understanding the Implementation of Small-Scale Water and Other Infrastructure Developments in Small Islands in Indonesia: A Rapid Survey in Bintan and Mandeh Islands
}

\author{
Pitri Yandri ${ }^{1, *}$, FX Hermawan Kusumartono ${ }^{2}$, Nanang Rianto ${ }^{2}$, Intan Adhi Perdana Putri ${ }^{3}$ \\ ${ }^{1}$ Ahmad Dahlan University of Technology and Business Jakarta, Jl. Ir. H. Juanda No. 77, Cirendeu, \\ Ciputat Timur, Tangerang Selatan, Banten, 15419, Indonesia \\ ${ }^{2}$ Research Center for Policy and Technology Application, Ministry of Public Works Republic of \\ Indonesia \\ ${ }^{3}$ Research Center for Population, LIPI, Jl. Gatot Subroto No.Kav 10, Jakarta Selatan, Jakarta 12710, \\ Indonesia \\ *) Corresponding Author (e-mail: p.yandri@gmail.com)
}

Received: 12 November 2019 / Accepted: 02 November 2020 / Published: 07 December 2020

\begin{abstract}
Access to clean water and electricity is one of the sustainable development agendas being addressed worldwide. However, people living on small islands scattered throughout Indonesia still face difficulties in accessing clean water and electricity. In an effort to overcome this problem, the Indonesian government and other donors are building small-scale cleanwater infrastructure in a number of these small islands. Other infrastructure, such as electricity supply, has also been developed in a number of places. The infrastructure framework for these works is directed toward community-based management efforts. However, various problems have emerged after the construction of these facilities. Instead of achieving increased community participation in their management, the opposite occurs. This article investigates this situation using a rapid survey of communities in Bintan Island and Kapo-Kapo Island in the Mandeh Waters area, and finds that the development of small-scale infrastructure has a different impact on the two regions observed. An elaboration of various field findings is presented in detail in this article.
\end{abstract}

Keywords: Pamsimas, Community, Water Infrastructure, Institution, Participation.

\section{Introduction}

Indonesia contains14,752 islands with a coastline of 95,181 kilometers and a sea area of 5.6 million $\mathrm{km}^{2}$. Of these, ten thousand small islands have the potential for prospective asset development of large coastal natural resources-the term "prospective" being applied here because this potential is supported by marine and fisheries resources with high economic value. In addition, $60 \%$ of Indonesia's population live in coastal areas and relies on marine and fisheries resources for their livelihood. Case studies conducted by Siregar (2008) in East Kalimantan, for example, prove that small islands have social, economic, cultural, political, and even security/land potential.
Effective management of small islands can therefore certainly contribute to the welfare of local communities.

The Indonesian government enacted law 27/2007 concerning the Management of Coastal Areas and Small Islands. This law states that small islands are those with an area of less than or equal to $2,000 \mathrm{~km} 2$ and with ecosystem integrity. However, so far there has been little evidence of the intentions of this law being realized. A study conducted by Tahir et al. (2009) on Barrang Lompo-Makasar Island, for example, found that the island was very vulnerable (with vulnerability index of 8.33), with the highest vulnerability parameters relating to tsunami events, population growth, and density, 
elevation, slope, and land use. The problem of plastic waste is also a problem for small islands, especially those being developed as tourist destinations (Syakti et al., 2018). Other studies have also mentioned that small islands, especially outermost islands, are at risk of sinking as a result of rising sea levels, earthquakes, and changes in land use and landscape resulting from the construction of ports, public-service buildings, and commercial areas (Prabowo and Salahudin, 2016; Kurniawan et al., 2016).

Other empirical evidence shows that small islands are still faced with problems caused by low-quality infrastructure, such as the availability of clean water and sanitation facilities. Susilawaty et al. (2016) study proves that, on small islands, the higher the extent to which the physical quality of clean water does not meet the requirements of the population, the greater the risks that can arise. In addition, a comprehensive study conducted by Azmanajaya (2012) on Tarakan Island found that the island faced an unsustainable situation, especially when looked at in terms of infrastructure and technology parameters. The results of a dynamic model simulation conducted by Azmanajaya (2012) found that by 2030 the island would experience a cleanwater crisis and recommended strategies and scenarios to improve the status of water supply by making comprehensive improvements.

At community level, the role of local communities in improving infrastructure in their environments has been investigated, especially in looking at how they survive economically (Fitriansah, 2012; Kusumatantya, 2013; Wibowo et al., 2016) and at how local institutions, with all the values of their beliefs, can adapt to climate change (Subair et al. 2013). Therefore, what is needed by local communities are efforts to provide understanding and training that can add to and strengthen the steps they have already taken (Djamhoer et al., 2014).

In addressing this issue, the Ministry of Public Housing (PUPR) prepared a Strategic Plan for 2015 -2019 through Minister of PUPR RI Regulation No. 13.1/PRT/M/2015. One of the strategies within this plan is to improve the quality of infrastructure in the small islands of Indonesia. One of the government's intervention programs on small islands is infrastructure development through simple technology applications, and this simplicity is intended to facilitate the community in participating in both maintenance and monitoring. These technologies include rainwater-recycling artificial aquifers (ABDULAH), composter waste, water and sewage treatment for households, and the "Pamsimas" program, which is a clean-water supply program implemented by the government of Indonesia with the support of the World Bank (World Bank, 2014).

However, many studies report that the quality of infrastructure development is often unsatisfactory due to poor maintenance and inadequate management (McCawley, 2015). On the other hand, case-study evidence about community participation in management of government-built infrastructure is still lacking. Among the limited research that has been conducted, Mujiyani et al. (2002) study in the Thousand Islands, for example, found that the role of residents in environmental management still seemed "modest", due to limited access to facilities and infrastructure. Faced with this situation, Hidayah et al. (2016) suggested the need for community empowerment through education, provision of live support facilities, and financial support from the government, and concluded this was essential to maintaining environmental protection and enhancing the prospects for sustainable management of the island studied.

\section{Research Method}

Based on this description of the current situation, we seek to understand the role of small-scale infrastructure in responding to the challenges and problems of people on small islands in Indonesia. To investigate this topic, we use rapid assessment surveys ("mini surveys") (Davis et al., 2009) to gather information on knowledge, attitudes, skills, and behavior related to the developed small-scale infrastructure in small-island 
communities. Mini surveys are usually based on a short, structured questionnaires containing standardized questions and tend to be administered to between 25 and 50 people at a time. Respondents can be selected through probability sampling techniques, or "convenience" sampling (interviewing stakeholders at locations where they are likely to be or where they get in contact with the campaign). The significant advantage of the mini survey is that the data can be collected and analyzed within a few days. Several researchers have used this technique in their studies, such as Fleming and Henkel (2001), who observed the successful implementation of education and health programs, and Manomano and Kangethe (2015) who explored the construction of housing projects in the Eastern Cape.

The survey instrument of this study is a structured questionnaire together with interviews and observations, these being used to explore the answers from respondents gathered from the questionnaire. Furthermore, observation is used to identify the types of developed infrastructure and photo documentation is provided as supporting data.

In this study, we took Bintan Island and Mandeh Island as our observation objects.

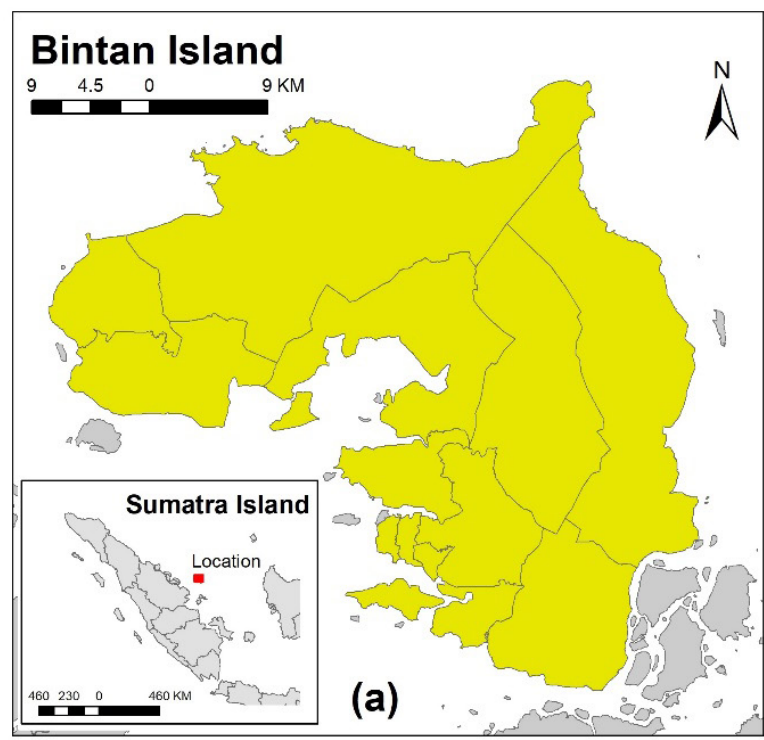

Figure 1. Location of study. (a) Bintan Island, (b) Mandeh Waters area, West Sumatra.

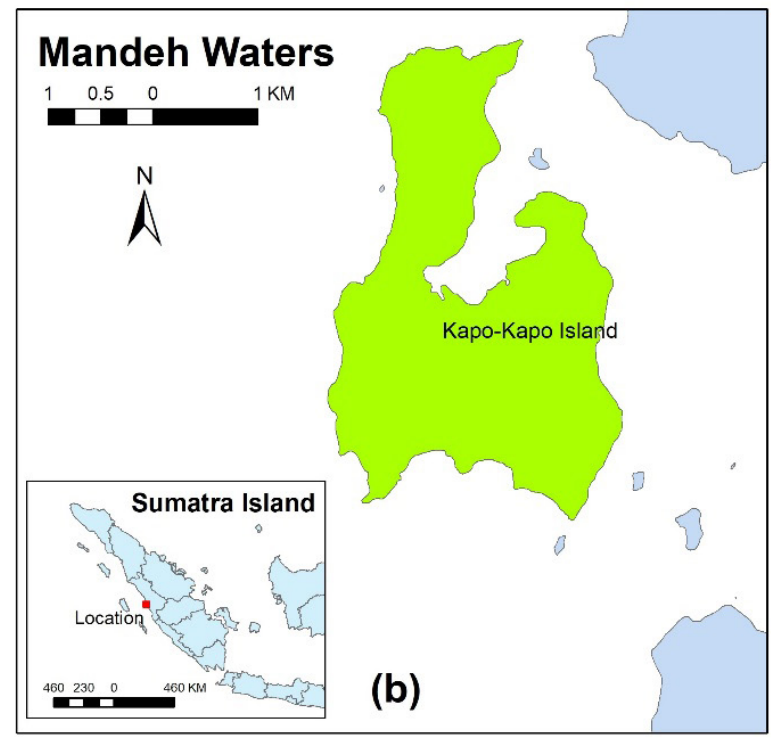

Bintan Regency was established through Government Regulation No. 5/2006 concerning the Changing of Riau Islands Regency Name to Bintan Regency Riau Islands Province, dated February 23, 2006. Geographically, Bintan Regency is located between latitudes 104 degrees north and 120 degrees south and longitudes 104 and 108.30 degrees east (See Figure 1a). Overall, the area of Bintan Regency is $87,411.92 \mathrm{~km} 2$, consisting of land area of $1,319.51 \mathrm{~km} 2(1.50 \%)$ and sea area of $86,092.41$ $\mathrm{km} 2(98.50 \%)$. Bintan Regency has 240 large and small islands, of which 49 are inhabited. The remainder, although currently uninhabited, support agricultural activities, in particular, plantations.

Mandeh is an area on the edge of a bay located in the Koto XI Tarusan subdistrict, Pesisir Selatan Regency, West Sumatra Province. In this area almost all districts are bordered by the sea. Of the total area, 84,312 $\mathrm{km} 2$ comprises waters with coastline length of approximately $234 \mathrm{~km}$. In these waters, there are 47 small islands with area of approximately $1,212.67 \mathrm{~km} 2$ (Figure 1b). Mandeh itself is a village (nagari) with an area of $6.48 \mathrm{~km} 2$, comprising $1.52 \%$ of the total area of Koto XI Tarusan District. 


\section{Results and Discussion}

\subsection{Bintan Island}

The observation was conducted in Berakit Village, one of seven villages in the Sebong Bay District (Figure 2). The area of this village is $30.65 \mathrm{~km}^{2}$. Secondary data tracking reveals that this village is one of Bintan Regency's, and even the nation's, higher-achieving villages. In 2016, for example, this village received the largest allocation of village funds of all villages in Bintan Regency, at Rp2,105 billion (http://www.tanjungpinangpos.co.id/). Administratively, Berakit Village consists of two hamlets, four citizen areas (RW), and eight neighborhood areas (RT). The distance from the village office to the subdistrict city is $\pm 62 \mathrm{~km}$, to the capital city district is $\pm 61 \mathrm{~km}$, and to the provincial capital is \pm 67 . Sebong Bay District Profile Data (2017) states that the number of families in this village comprises 612 households with 1,842 total population. Out of 514 households recorded, there were still 23 households that used non-state electricity company (PLN) electricity resources.

Berakit Village is a maritime rural area, with the livelihoods of the majority of the population being in the fisheries sector. Other livelihoods are in agriculture, plantations, and small-industry sectors engaged in the study and utilization of processed fishery products. Based on data updates in December 2015, the population of Berakit Village was 1,747 people with demographic characteristics as presented in Tables 1 and Table 2.

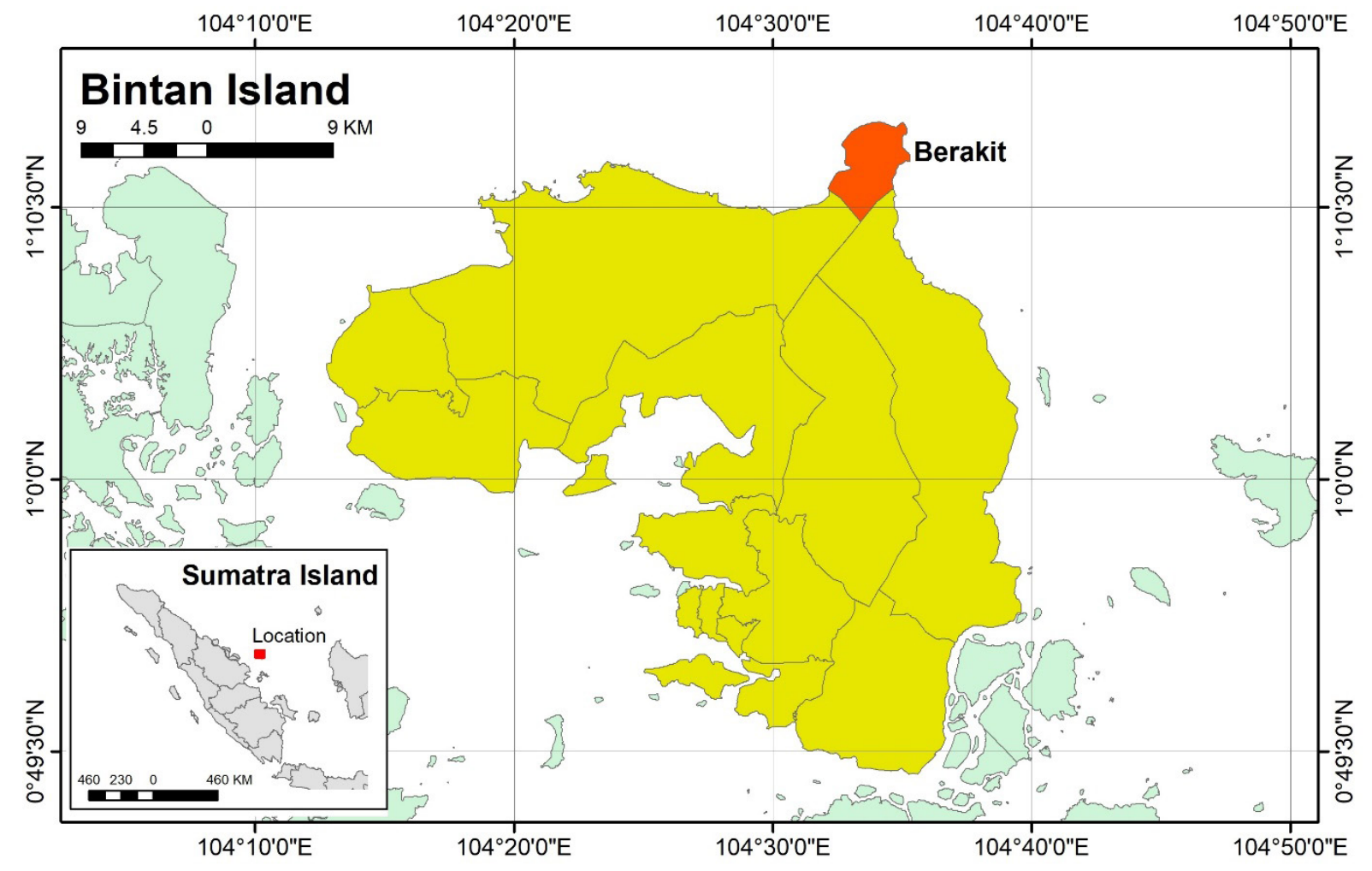

Figure 2. Location of Berakit Village in Sebong Bay District.

Table 1. The population of Berakit Village.

\begin{tabular}{ccccc}
\hline \multirow{2}{*}{$\begin{array}{c}\text { Neighborhood } \\
\text { area (RT) }\end{array}$} & Citizen area (RW) & \multicolumn{3}{c}{ Total population } \\
\cline { 3 - 5 } & & Male & Female & Male + female \\
\hline 001 & I & 170 & 179 & 349 \\
002 & I & 112 & 115 & 227 \\
003 & II & 46 & 54 & 100 \\
004 & II & 90 & 94 & 184 \\
\hline
\end{tabular}




\begin{tabular}{|c|c|c|c|c|}
\hline \multirow{2}{*}{$\begin{array}{l}\text { Neighborhood } \\
\text { area (RT) }\end{array}$} & \multirow{2}{*}{ Citizen area $(\mathrm{RW})$} & \multicolumn{3}{|c|}{ Total population } \\
\hline & & Male & Female & Male + female \\
\hline 005 & III & 106 & 107 & 213 \\
\hline 006 & III & 111 & 97 & 208 \\
\hline 007 & IV & 137 & 131 & 268 \\
\hline 008 & IV & 100 & 98 & 198 \\
\hline \multicolumn{2}{|c|}{ Total } & 872 & 875 & 1,747 \\
\hline
\end{tabular}

Source: RPJMDes Berakit, 2017

Table 2. Occupations of the population of Berakit Village

\begin{tabular}{lcc}
\hline \multicolumn{1}{c}{ Type of work } & Number of people & $\%$ \\
\hline Farmer & 188 & 10.73 \\
Fisherman & 338 & 19.30 \\
Farm worker & 25 & 1.42 \\
Small trader & 1 & 0.005 \\
Transportation & 2 & 0.11 \\
Civil servant & 27 & 1.54 \\
Civil servant honorary & 72 & 4.11 \\
Armed forces & 2 & 0.11 \\
Pensioner & 2 & 0.11 \\
Stock farmer & - & - \\
Student & 482 & 27.52 \\
Entrepreneur & 35 & 1.99 \\
Carpentry & 1 & 0.005 \\
Others & 576 & 32.89 \\
$\Sigma$ & 1,751 & 100 \\
\hline
\end{tabular}

Source: Berakit Village Profile, 2016

Table 3. Problems with public works and water resources raised in the village assembly.

\begin{tabular}{|c|c|c|}
\hline \multirow{2}{*}{ Problems } & \multicolumn{2}{|c|}{ Location } \\
\hline & Sub-village I & Sub-village II \\
\hline \multicolumn{3}{|l|}{ Public works issues: } \\
\hline $\begin{array}{l}\text { The number of roads/TPT in the hamlet that are damaged, narrow, and } \\
\text { still in the form of unconsolidated land, so the road is muddy in the rainy } \\
\text { season and dusty in the summer }\end{array}$ & $\sqrt{ }$ & $\sqrt{ }$ \\
\hline During the rainy season, the roads are muddy and slippery & $\sqrt{ }$ & $\sqrt{ }$ \\
\hline \multicolumn{3}{|l|}{$\begin{array}{l}\text { Public transportation facilities do not support adequately, because there is a } \\
\text { lack of transportation that can reach all areas of the village }\end{array}$} \\
\hline Road conditions around many are still not passable. & $\sqrt{ }$ & $\sqrt{ }$ \\
\hline $\begin{array}{l}\text { Many alleyways in every RT/RW have already been damaged and most of } \\
\text { them consist of land that has not been of one type }\end{array}$ & $\sqrt{ }$ & $\sqrt{ }$ \\
\hline Many residents' facilities are in poor repair because they are old & $\sqrt{ }$ & $\sqrt{ }$ \\
\hline \multicolumn{3}{|l|}{ Water resource issues: } \\
\hline $\begin{array}{l}\text { There are still many damaged drainage channels (household waste } \\
\text { disposal) }\end{array}$ & $\sqrt{ }$ & $\sqrt{ }$ \\
\hline
\end{tabular}




\begin{tabular}{lcc}
\hline \multicolumn{1}{c}{ Problems } & \multicolumn{2}{c}{ Location } \\
\cline { 2 - 3 } & Sub-village I & Sub-village II \\
\hline Public works issues: & $\sqrt{ }$ & $\sqrt{ }$ \\
In the dry season, almost $45 \%$ of people lack water & $\sqrt{ }$ \\
The springs are not maintained properly & $\sqrt{ }$ \\
\hline
\end{tabular}

Source: RPJMDes Berakit, 2017

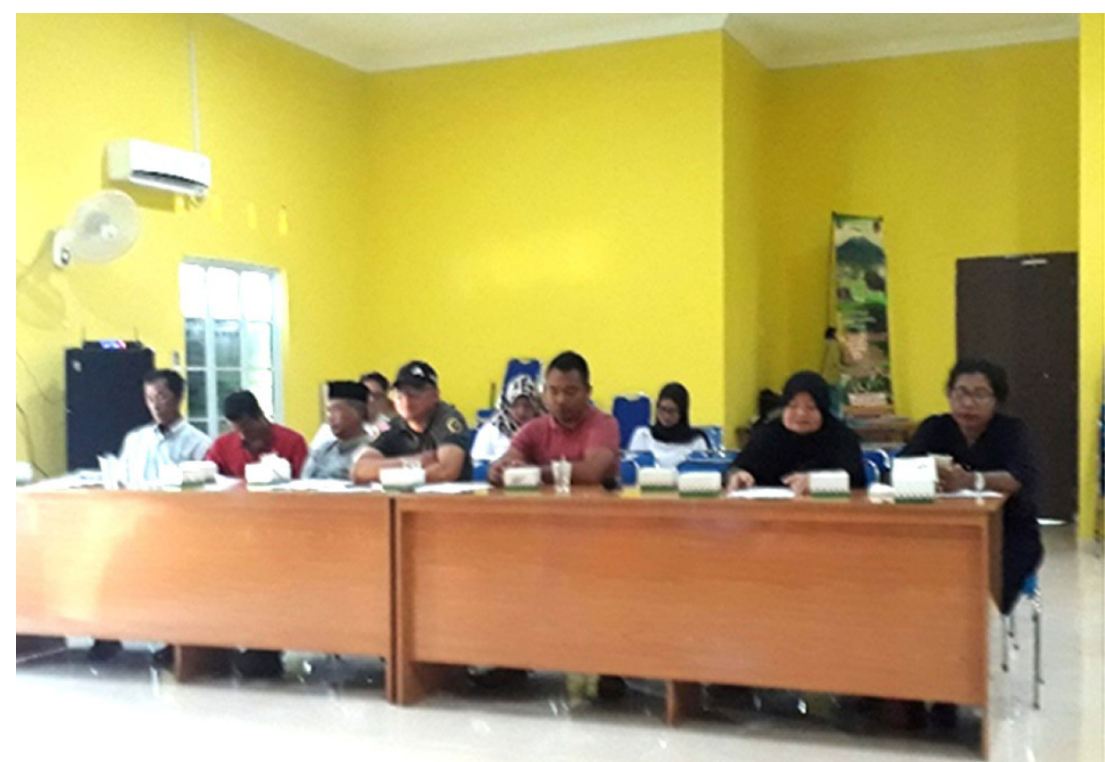

Figure 3. FGD with the residents of Berakit Village at the Berakit Village Office.
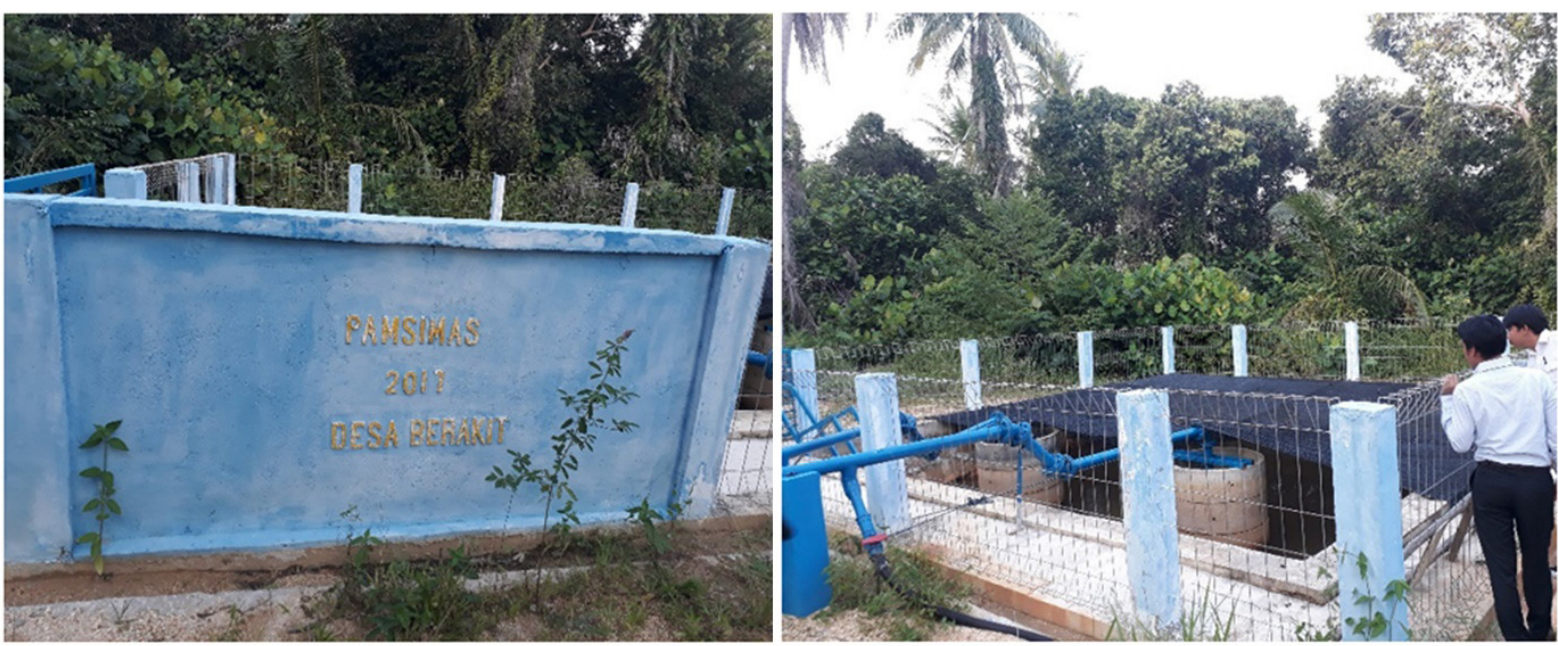

Figure 4. Pamsimas Infrastructure in Berakit Village.

In the village's medium-term resources; (3) problems in the environmental development plan (RJPMD) documents, field; (4) problems in the field of education; successful identification of infrastructure (5) problems in the health sector; (6) problems problems is reported. These problems are in the social field; (7) problems in governance divided into (1) public works/infrastructure and institutions; (8) problems in the religious issues; (2) problems in the field of water field; and (9) problems in the economic field. 
A detailed matrix of problems in the fields of public works/infrastructure and water resources is presented in Table 3. The RPJMD Berakit Village document was a focus group discussion (FGD) confirmation tool that had been used with the Bintan District Government the day before our study. From the FGD, information was obtained that indicated the main problem faced by Berakit Village was the difficulty in obtaining clean water.

More detailed information was also gathered during the FGD with residents (Figure 3) and the Head of Berakit Village, Muhammad Adam. The following section describes the views conveyed by the village head and the residents. In the FGD session, we found that clean water was indeed a significant problem in this village. While the water available is clean enough to be used for bathing and washing, it cannot be used for drinking because the groundwater available is brackish; for bathing and washing, the residents access water by digging wells.

However, to fulfill drinking water requirements, Berakit Village has implemented a Community-Based Water Supply and Sanitation (Pamsimas) development. Pamsimas is a program implemented in rural and suburban areas by the government of Indonesia with the support of the World Bank. The internet portal of Pokja Drinking Water and Environmental Sanitation (Pokja AMPL) states that the Pamsimas program aims to increase the number of facilities for underserved residents, including low-income people in rural and peri-urban areas. With the aid of Pamsimas, residents are expected to be able to access sustainable water and sanitation services and thus to be able to follow clean and healthy living behaviors. The implementation of this program supports the achievement of Millennium Development Goal targets (drinking water and sanitation sector) through mainstreaming and expanding communitybased development approaches (http:/ / www. ampl.or.id/). Clean water is essential, and so infrastructure that can ensure its supply is an essential prerequisite for human development (Tortajada, 2014).

The scope of the Pamsimas program includes five components: (1) community empowerment and regional and village institutional development; (2) improvement of hygienic behavior and sanitation services; (3) provision of drinking water and public sanitation facilities; (4) incentive grants; and (5) technical support and management of program implementation (http:/ / new.pamsimas.org).

The Pamsimas plan for Berakit Village was designed in 2016, and implemented and operated from 2017 (Figure 4). In terms of the physical infrastructure, Pamsimas assets are owned by the village, and the budget planning for it uses village budgeting supported by the Bintan Regency regional budget. The scheme adopted by Pamsimas in supplying drinking water needs is to sell water to residents for Rp5000 per gallon, each gallon supplying 10 liters of water ready to be boiled for drinking. Since the Pamsimas infrastructure came into operation, the problem of lack of water for the village has been solved. The Pamsimas facility operates through pumping groundwater and water from wells (Figure 5) that is then channeled to a holding center/container (Figure 5c) through a pipeline (Figure $5 d$ ). There are four water reservoirs each with a capacity of 5000 liters, a total water capacity of 20,000 liters.

In terms of institutional governance, the Pamsimas development is purely managed by the community and institutional devices such as organizational structure and management are well structured. In terms of participation, the Pamsimas project in Berakit Village is quite useful in involving citizens in the decisionmaking process. Based on its governance, the Pamsimas in Berakit Village has been recognized as the best local community for Pamsimas governance and has become an example of best practice for other regions in Indonesia. 

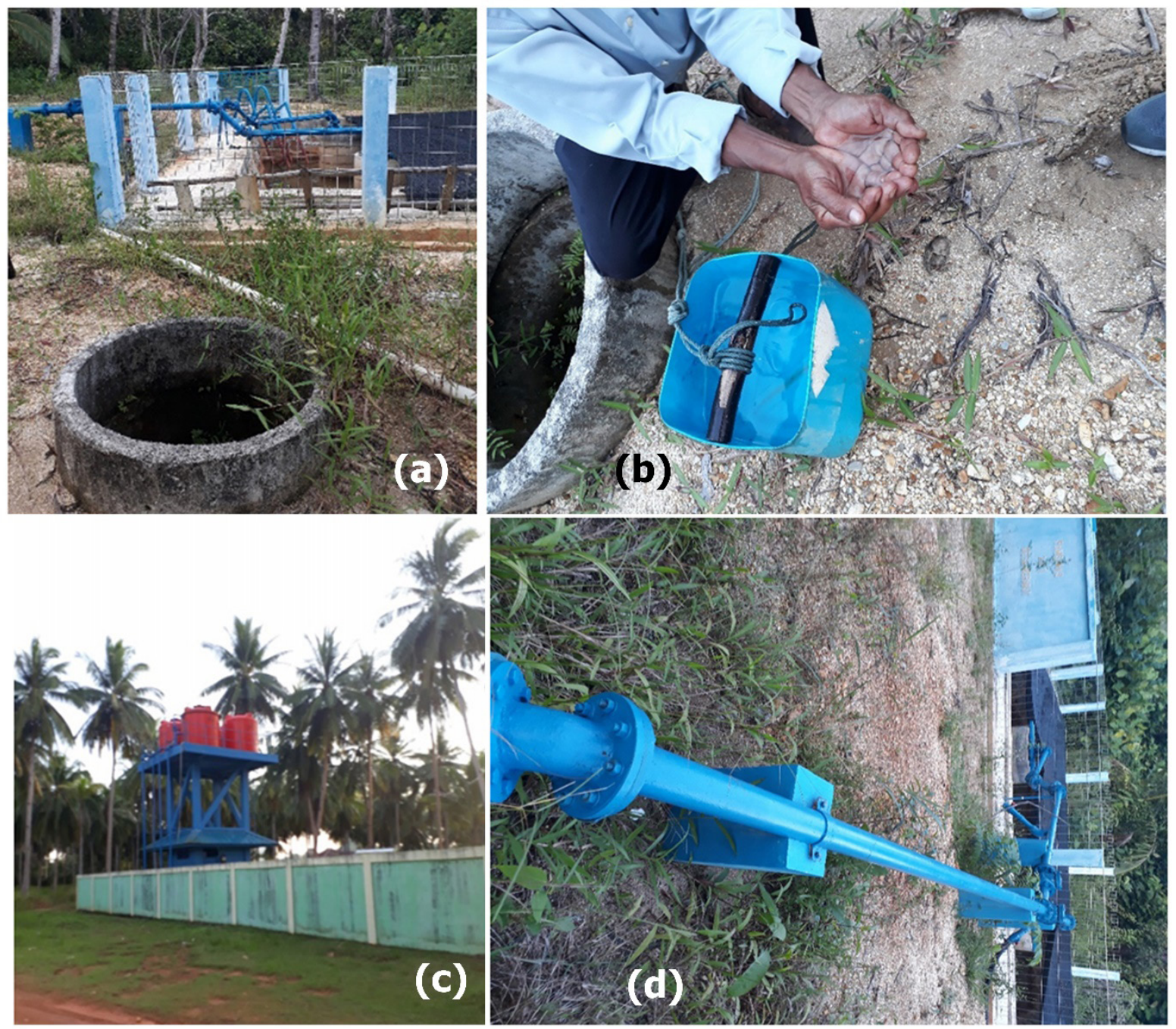

Figure 5. The Pamsimas facilities. (a) Pamsimas water well in Berakit Village, (b) Pamsimas well water quality, (c) Pamsimas water container in Berakit Village, and (d) Pamsimas pipeline to container in Berakit Village.

\subsection{Mandeh Island}

Mandeh is known as a marine tourism area

(Figure 12). A number of secondary sources mention that there are at least seven attractions that can be visited in this area, namely: (1) Mandeh Peak (Figure 12b); (2) Sironjong Gadang Island; (3) Sironjong Ketek Island; (4) Kapo-Kapo Village and mangrove forests; (5) Sutan/Satan Island; (6) Rumble River and waterfall; and (7) Cubadak Island. Apart from Mandeh Peak, all other attractions can only be reached by sea transportation. However, in the Koto XI Tarusan subdistrict as a whole, the attractions available are not limited to marine tourism and the number of tourism sites and their distribution data in some of the area's villages.
As a tourist area, the main problem faced by District XI Koto Tarusan is environmental waste, an issue revealed in the FGD session conducted by the South Coastal Regency Government service. From the inventory list of problems that surfaced, each agency stated that waste is a problem that is handled well. In searching for secondary information, it is evident that the local government has sought to ensure that waste at marine tourism sites in Mandeh is appropriately handled. The local government is collaborating with the Tourism Awareness Group (Pokdarwis) to minimize waste in the Mandeh Integrated Marine Tourism Area (KWBT) by carrying out routine clean-up (https://sumbar.antaranews.com, 29 July 2018). 


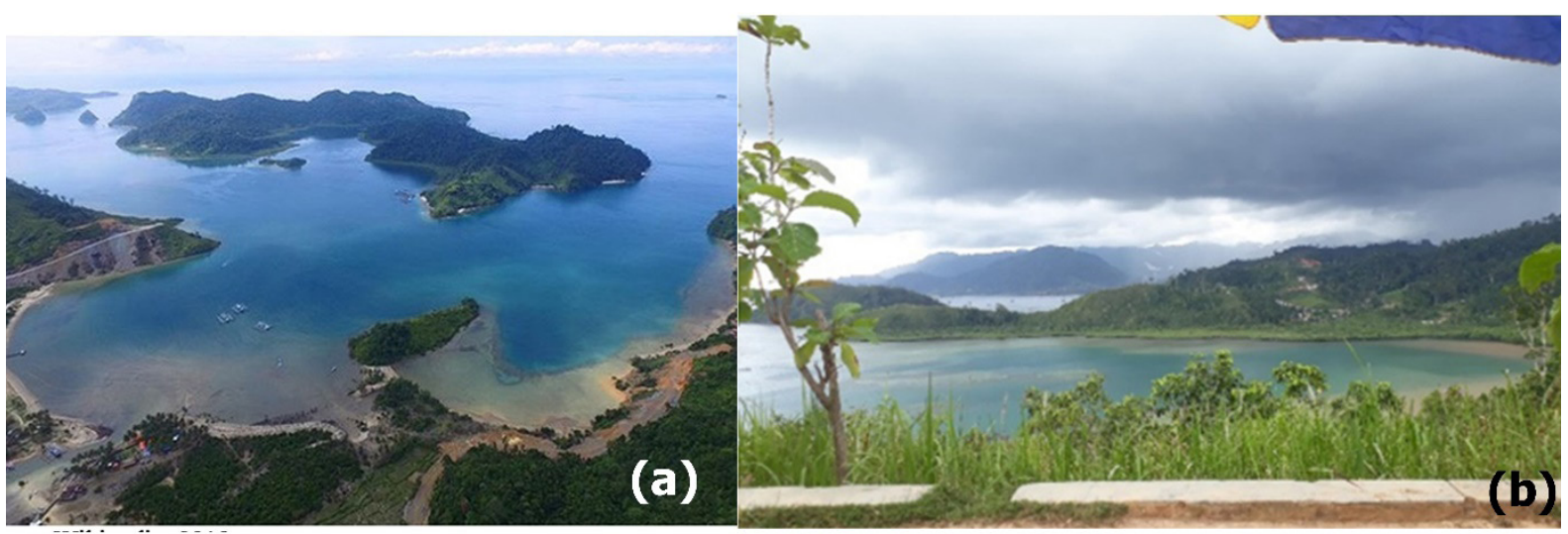

Figure 6. Mandeh Bay. (a) Photo taken from the air, (b) photo taken from Mandeh Peak.
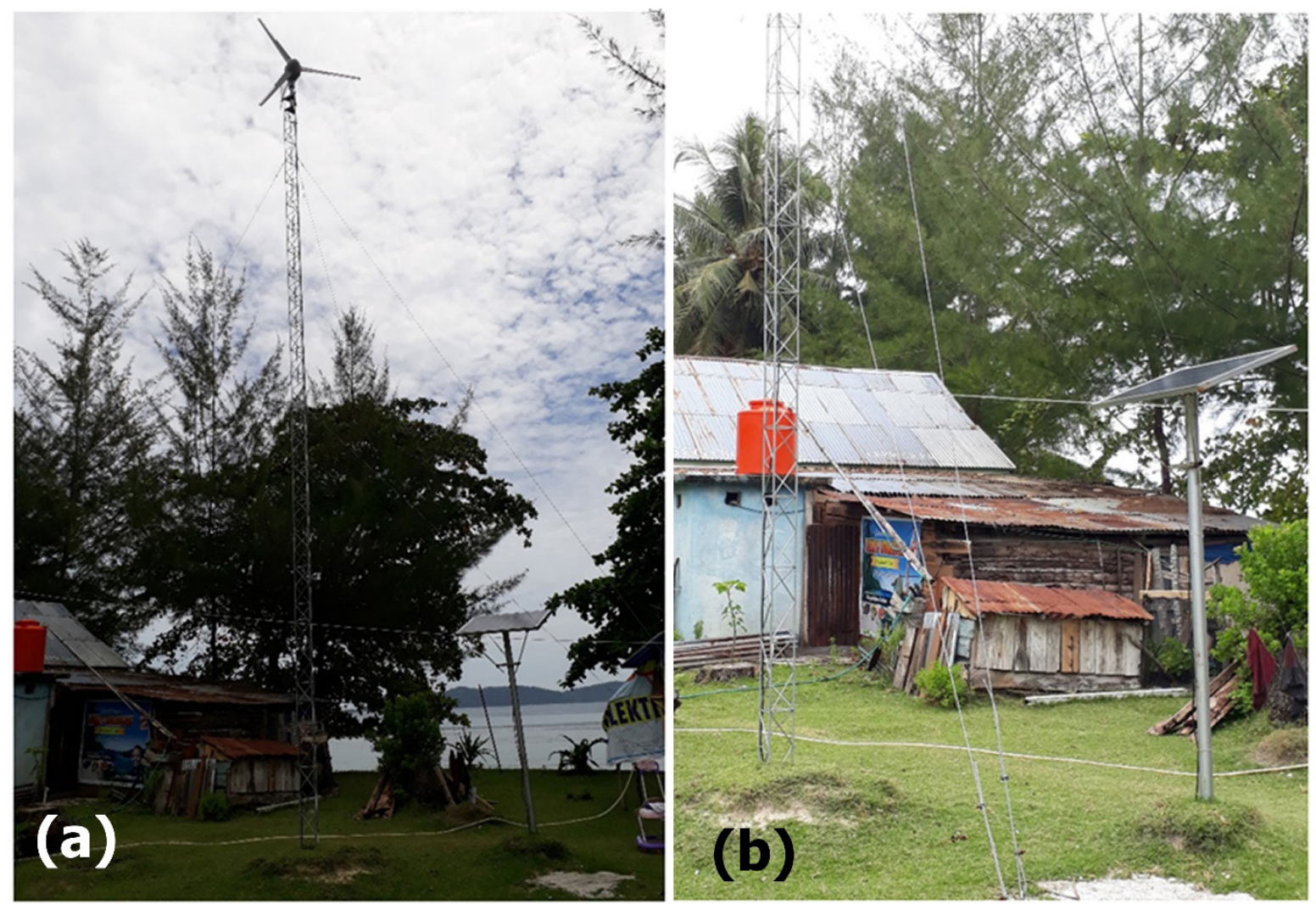

Figure 7. Power plants on Kapo-Kapo Island. (a) wind power plant, (b) solar panel power plant.

Besides waste, another problem faced is the scarcity of clean water. The community is very dependent on the Tirta Langkisau Regional Water Company (PDAM) in meeting their needs for clean water. This dependency is illustrated by an event in 2012, in which clean-water pipes provided by PDAM were damaged, resulting in 3,200 households experiencing a clean-water crisis (https:// sumbar.antaranews.com, 18 October 2012). At present, PDAM Tirta Langkisau has provided
12 installation points for clean-water channels (intakes) and these 12 intakes have been connected to 22,000 channels supplying the public. With a requirement for clean water for the community of 104,596 households spread across 182 villages in Pesisir Selatan Regency, local communities have stated that they need four more installation points to enable optimization of clean-water provision to the community (http://news.klikpositif.com, 6 February 2018). 
Meanwhile, field findings on Kapo-Kapo Island identify another problem. Kapo-Kapo is a small island located in Sei Nyalo Mudiak Aia (Figure $1 b$ ). Clean water is relatively available, with evidence that the island of 60 people or 22 households has a storage capacity of 2000 liters. The island's water container is on a small hill that can be reached by walking a short distance. Toren functions as a reservoir of clean water which then flows to a water collection center in the mushala adjacent to the residents' homes.

The main problem on this island is electricity supply, with electricity needs being met by privatly purchased generators. These are not available to all households because of their price of around Rp8 million per unit. To overcome this, the South Pesisir Regency Government, together with the islanders and in collaboration with the Indonesian Institute of Sciences (LIPI), built a wind-powered plant (hybrid wind turbine) with three generator units in 2017 (Figure 7a). This power plant is integrated with solar-power plants that had already been built (Figure $7 \mathrm{~b}$ ). This installation has been operating since 2018 and this simple infrastructure can sufficiently overcome the electricity problems that have been faced by residents for years.

However, based on information obtained from residents through interviews, the electricity supplied by the equipment lasts only for two hours per day. Furthermore, residents cannot use it for watching television because if they do so, the duration of electricity supply is reduced. In other words, the electrical installation is limited to providing power for lighting.

The infrastructure management system has not been clearly explained to residents, who stated that the infrastructure assets were owned by the village guardians. However, monitoring and daily management are left to residents. This situation is also not specific about "who manages what." Thus it seems that this infrastructure development raises complicated institutional problems. These include, for example, that although the installation is faced with the likelihood of damage and breakdown, the installation itself does not include information about where residents have to report such damage or malfunctioning. From the perspective of Ostrom (1999), this situation endangers the sustainability of the infrastructure. It is clear that this wind/ solar-power plant infrastructure developed by LIPI is not yet based on local community management.

\section{Conclusion}

Indonesia is a country composed of thousands of islands, both inhabited and uninhabited. On inhabited islands, local people face various problems, particularly in obtaining clean water. The problem is getting worse because of the lack of infrastructure supplying clean water to the community, and this means that local people have to survive in difficult water-supply situations. Various program interventions are carried out to address these problems, both by the government and donor agencies. These programs take the form of small-scale infrastructure developments with community-based management. However, infrastructure development often faces obstacles caused both by quality issues and by other technical obstacles such as the adaptation of local communities to the technology and the low participation of the community in its management.

This situation led us to explore information about the role of small-scale water infrastructure developments in local communities. We observed two islands which were considered to be representative namely Bintan Island and Mandeh Island in West Sumatra. Using a rapid survey technique, we gained valuable information about how cleanwater infrastructure is managed and its role in the local community.

On Bintan Island, and especially in Berakit Village, clean-water infrastructure was built through the Pamsimas program. The management of Pamsimas in this village is quite good and there is citizen participation in the decision-making process. Formal institutional 
devices such as organizational structure and management are fairly well institutionalized. Through this program, local people are quite active in managing clean water in their villages.

In the Mandeh area, especially on the island of Kapo-Kapo, people still experience water shortages although the local government provides a water storage infrastructure that can be used by the community. In addition to the problem of clean water, residents also face problems with electricity supply. To address this issue, the LIPI government research institute built a solar-powered generation panel but the problem remains that the development is not accompanied by clarity about who manages what. This infrastructure development therefore raises complicated problems relating to institutional arrangement.

\section{Acknowledgments}

This study is part of the Ministry of Public Works and Public Housing infrastructure implementation policy research, 2018. Our thanks go to the Research Center for Policy and Technology Applications, Ministry of Public Works of Republic of Indonesia for funding this research.

\section{References}

Azmanajaya, E., (2012), Model Penyediaan Air Bersih Berkelanjutan di Pulau Kecil (Studi Kasus: Pulau Tarakan, Kalimantan Timur), Tesis, Fakultas Teknologi Pertanian, Institut Pertanian Bogor, Bogor.

Barclay, N., \& Klotz, L., (2019), Role of Community Participation for Green Stormwater Infrastructure Development, Journal of Environmental Management, 251: 1-9.

Davis, R., Luna, J., Rodriguez, A., \& Sarriot, E. (2009), Rapid Health Surveys: Principles and Sampling Design Handbook. ICF Macro: Calverton, MD.

Djamhoer, M., Boer, M., Bengen, D.G., \& Fahrudin, A., (2014), Pemodelan Interpretasi Struktural Pengembangan Kawasan Pesisir dan Pulau-Pulau Kecil di Teluk Weda, Jurnal Sosek KP, Vol. 9, No. 2: 127-140.

Fitriansah, H., (2012), Keberlanjutan Pengelolaan Lingkungan Pesisir Melalui Pemberdayaan Masyarakat di Desa Kwala Lama Kab. Serdang Bedagai, Jurnal Pembangunan Wilayah dan Kota, Vol. 8 (4): 360-370.

Fleming, B., \& Henkel, D., (2001), Community-Based Ecological Monitoring A Rapid Appraisal Approach, Journal of the American Planning Association, Vol. 67, No. 4: 456-465.

Hidayah, Z., Rosyid, D.M., \& Armono, H.D., (2016), Planning for Sustainable Small Island Management: Case Study of Gili Timur Island East Java Province Indonesia, ProcediaSocial and Behavioral Sciences, Vol. 227: 785-790.

Kurniawan, F., Adrianto, L., Bengen, D.G., \& Prasetyo, L.B., (2016), Patterns of Landscape Change in Small Island A Case of Gili Matra Island Marine Tourism Park, Indonesia, ProcediaSocial and Behavioral Sciences, Vol. 227: 553-559.

Kusumatantya, I., (2013), Peran Pemangku Kepentingan dalam Pembentukan Komunitas Guna Mencapai Ketahanan Sosial Ekonomi Masyarakat, Jurnal Wilayah dan Lingkungan, Vol. 1, No. 1: 33-48.

Manomano, T., \& Kang' ethe, S.M., (2015), Exploring the Administrative and Managerial Flaws Associated with Reconstruction and Development Program (RDP) Housing Projects: the Case of Alice Golf Course Housing Project, Eastern Cape, Journal of Human Ecology, 49 (3): 263-271. 
McCawley, P., (2015), Infrastructure Policy in Indonesia, 1965-2015: A Survey, Bulletin of Indonesian Economic Studies, Vol. 51, No. 2: 263-285.

Mujiyani, Hidayati, D., Rachmawati, L., Soetopo, T., Aji, G.B., \& Cahyadi, R., (2002), Pengelolaan Pulau-Pulau Kecil: Partisipasi Masyarakat di Kepulauan Seribu, Pusat Penelitian Kependudukan, LIPI, Jakarta.

Ostrom, E., 1990, Governing the Commons: The Evolutions of Institutional for Collective Action, UK: Cambridge University Press.

Prabowo, H.H., \& Salahudin, M., (2016), Potensi Tenggelamnya Pulau-Pulau Kecil Terluar Wilayah NKRI, Jurnal Geologi Kelautan, Vol. 14, No. 2: 115-122.

Siregar, C.N., (2008), Analisis Potensi Daerah Pulau-Pulau Terpencil dalam Rangka Meningkatkan Ketahanan Pangan, Keamanan Nasional, dam Keutuhan Wilayah NKRI di Nunukan Kalimantan Timur, Jurnal Sosioteknologi, Edisi 13, Tahun 7: 345-368

Subair, Kolopaking, L.M., Adiwibowo, S., \& Pranowo, M.B., (2013), Kelembagaan Lokal dan Adaptasi Perubahan Iklim pada Komunitas Nelayan di Pulau Ambon Maluku, Masyarakat, Kebudayaan, dan Politik, Vol 26, No. 2: 80-89.

Susilawaty, A., Amansyah, M., \& Nildawati, (2016), Kerentanan Ketersediaan Air Bersih di Daerah Pesisir dan Pulau-Pulau Kecil Sulawesi Selatan Indonesia, Al-Sihah: Public Health Science Journal, Vol 4, No. 2: 194-203.

Syakti, A.D., Hidayati, N.V., Jaya, Y.V., Siregar, S.H., Yude, R., Suhendy, Asia, L., Chung, P.W.W., \& Doumenq, P., (2018), Simultaneous Grading of Microplastic Size Sampling in the Small Islands of Bintan Water, Indonesia, Marine Pollution Bulletin, 137 (2018): 593-600.

Tahir, A., Boer, M., Susilo S.B., \& Jaya, I., (2009), Indeks Kerentanan Pulau-Pulau Kecil: Kasus Pulau Barrang Lompo-Makasar, Jurnal Ilmu Kelautan, Vol 14, (4): 183-188.

Tortajada, C., (2014), Water Infrastructure as an Essential Element for Human Development, International Journal of Water Resources Development, Vol. 30, No. 1: 8-19.

Wibowo, H., Bahri, E.S., \& Harto, P.P., (2016), Optimalisasi Peran Masyarakat Nelayan Batam dalam Pengembangan Ekonomi, SOSIO DIDAKTIKA: Social Science Education Journal, 3 (1): 92-104.

World Bank, (2014), PAMSIMAS: Responding to the Water and Sanitation Challenges in Rural Indonesia, Jakarta. 